EDUKACJA MIĘDZYKULTUROWA

2012, nr 1

ISSN 2299-4106

TADEUSZ LEWOWICKI

\title{
Edukacja międzykulturowa - bilans otwarcia 2012
}

Streszczenie: Artykuł jest swoistym bilansem dokonań i problemów edukacji międzykulturowej. Przedstawia próbę typologii odmian wielokulturowości oraz przykłady zjawiska wielokulturowości w różnych częściach świata. Na tym tle nakreślony został szkic dziejów edukacji wielokulturowej - celów tej edukacji, przyjmowanych modeli, a także skutków. Jako propozycja przezwyciężenia słabości edukacji wielokulturowej przedstawiona jest edukacja międzykulturowa. Nową tendencją w życiu współczesnych społeczeństw - przywołaną w artykule - staje się wielowymiarowe ujmowanie tożsamości człowieka. W warunkach globalizacji, europejskiej integracji, demokracji i respektowania praw ludzi ważne są możliwości dokonywania wyborów własnej tożsamości. Wymienione sprawy, a także inne sprawy sygnalizowane w tekście, wyznaczają istotne zadania edukacji międzykulturowej.

Słowa kluczowe: podstawy aksjologiczne, wielokulturowość, edukacja wielokulturowa, edukacja międzykulturowa, tożsamość, bilans i przesłania edukacji międzykulturowej.

Inauguracja rocznika poświęconego zagadnieniom edukacji międzykulturowej jest ważnym wydarzeniem w życiu akademickiego środowiska pedagogicznego, a także środowisk oświatowych. W wielokulturowym świecie, który coraz silniej oddziałuje na nasze społeczeństwo i w którym Polacy uczestniczą z coraz większym zaangażowaniem, sprawy edukacji mogą i powinny odgrywać znaczącą i przede wszystkim pozytywną rolę - powinny służyć zbliżeniu ludzi różnych kultur i ich pomyślnemu życiu, współpracy, rozwojowi. Wielokulturowość - chociaż jest zjawiskiem powszechnym - wciąż jednak nie wydaje się dostatecznie „oswojona”, wciąż pozostaje w dużej mierze marnowaną szansą wspólnego tworzenia dóbr kultury duchowej i materialnej, wielostronnej kooperacji, kształtowania warunków szczęśliwego życia ludzi różnych narodowości, ras, wierzeń, kultur. W integrującej się Europie i poddającym się procesom globalizacji świecie sprawy edukacji międzykulturowej 
stają się jednym z najważniejszych wyzwań. Ich znaczenie wykracza poza tradycyjne rozumienie środowiska oraz ramy wychowania i kształcenia. Od edukacji może zależeć przyszłość ludzkości dysponującej niekiedy trudnymi do wyobrażenia ich siły środkami - militarnymi, technologicznymi, gospodarczymi i ekonomicznymi. Środki te mogą być wykorzystane przeciwko lub dla dobra ludzi. Edukacja ma powinność kształtowania świata wartości, wiedzy, postaw, które prowadzić będą do pokojowego współistnienia, tolerancji, współpracy, godnych warunków życia, respektowania praw człowieka, wolności. Szczególne miejsce i rolę przypisać należy szeroko pojmowanej edukacji międzykulturowej.

Przywołując kategorię powinności edukacji, trzeba wszakże mieć świadomość, że nie wszyscy chcą je uznawać, niekiedy w ogóle odrzuca się przypisywane edukacji zadania, często deklaruje się aprobatę przywołanych powinności (także innych kojarzonych z oświatą), ale w praktyce przyjmuje się powinności inne (z jakiegoś powodu wygodne, pożądane). Tak bywa m.in. z kwestiami tolerancji, otwarcia na Innych i ich kultury, współpracy, równych praw. Polityczna poprawność deklaracji nie znajduje odpowiedniego odzwierciedlenia w przyjmowanych rozwiązaniach spraw oświaty. Takie postawy nie są zgodne z intencjami i praktyką edukacji międzykulturowej, a szerzej rzecz traktując - z przesłaniami edukacji służącej dobru ludzi.

Jeżeli więc na wstępie odwołuję się do wspomnianej kategorii edukacyjnych powinności (w ich ogólnoludzkim, uniwersalnym, pozytywnym znaczeniu), to podkreślam w ten sposób, że powinności edukacji są na gruncie edukacji międzykulturowej wyznaczane przez zespół wartości, które określa się jako uniwersalne, a które czerpią swe źródła zarówno z pozytywnych przesłań religii i wyznań, jak i odwiecznych doświadczeń i mądrości poprzednich pokoleń, jak też imperatywów nie czynienia zła a czynienia dobra, jak też wreszcie współczesnej myśli społecznej ukazującej pozytywne perspektywy życia w pokoju, wolności, w warunkach respektowania praw człowieka, solidarności, współpracy, a jednocześnie pluralizmu światopoglądowego i politycznego, zróżnicowania kultur. Taka deklaracja - pomimo nieuniknionej tu ogólnikowości - wyraźnie wskazuje na aksjologiczne fundamenty edukacji międzykulturowej. Wyznaczają one sposób rozumienia i uprawiania edukacji, ważne cele edukacyjne. Dotychczasowa praktyka edukacji międzykulturowej i publikowane ślady działalności w tym zakresie ${ }^{1}$ jednoznacznie potwierdzają

1 Por. np. publikacje z serii „Edukacja Międzykulturowa” - firmowanej przez Uniwersytet Śląski, Wydział Etnologii i Nauk o Edukacji w Cieszynie, a także Wyższą 
wierność tym aksjologicznym przesłaniom i napawają nadzieją. Przytoczenie fundamentów aksjologicznych i oparcie na nich swoistej ideologii i praktyki edukacyjnej wyznacza cele, treść i realizacje edukacji międzykulturowej.

Edukacja międzykulturowa wciąż jednak pozostaje obszarem życia społecznego niezbyt dobrze rozumianym, kojarzonym z rozmaitymi wcześniejszymi odmianami edukacji wielokulturowej. Idee i praktyka edukacji międzykulturowej dopiero zdobywają zrozumienie i miejsce w edukacji, w życiu społecznym. Nierzadko natrafiają na brak zrozumienia, niechęć, opór przed zmianą myślenia o edukacji i zmianą praktyki oświatowej. Wiele przyczyn składa się na problemy związane z upowszechnieniem (się) edukacji międzykulturowej. Jakie zatem są szanse oddziaływania tej edukacji? Jakie są przeszkody? Jakie perspektywy tworzy teoria pedagogiki międzykulturowej i praktyka edukacji międzykulturowej? To niektóre pytania, które zachęcają do ogólnego spojrzenia na tradycję, uwarunkowania i współczesne losy edukacji w warunkach wielokulturowości. To stanowi zachętę do próby dokonania bilansu otwarcia - w chwili, gdy ukazuje się nowy periodyk zorientowany na pedagogikę i edukację międzykulturową, a jednocześnie w czasie nasilonego procesu migracji ludzi, spotkań różnych kultur, a także wciąż ujawniających się konfliktów w wielokulturowym świecie, w którym nie brakuje opinii o kryzysie funkcjonowania społeczeństw i państw wielokulturowych. Ze względu na skalę i dynamikę zachodzących zjawisk jest to czas niezwykły, szczególny.

\section{Odmiany wielokulturowości}

Kwestie edukacji wielokulturowej i międzykulturowej w oczywisty sposób związane są ze zjawiskiem wielokulturowości. Warto więc najpierw poświęcić uwagę właśnie wielokulturowości - jej dziejom, swoistym odmianom, skali i skutkom.

Społeczności i społeczeństwa wielokulturowe powstawały w różnych okolicznościach, z różnych powodów i miały - oraz nadal mają - wiele cech różnych, ale i cechy wspólne. Różne były i są skutki powstawania takich społeczeństw, różne losy. Przywołajmy niektóre sprawy ilustrujące bogactwo i odmienność doświadczeń.

Szkołę Pedagogiczną ZNP w Warszawie, ponadto publikacje wydane przez uniwersytety w Białymstoku i Opolu. 
Jedną z najdawniejszych i - niestety - zbyt częstych okoliczności powstawania społeczeństw wielokulturowych są wojny. W ich wyniku brano jeńców, niewolników - ludzi mających swoje języki, kultury. Od czasów, gdy znaczenie zyskało terytorium, uprawne pola i bogactwa naturalne, $w$ wyniku wojen włącza się opanowane terytoria i ich mieszkańców do państw zwycięskich. Tak powstawała wielokulturowość obarczana przemocą, krzywdą, złymi doświadczeniami.

Wielokulturowość kształtowała się również w okolicznościach bardziej przyjaznych. Ludzie przemieszczali się powodowani ciekawością, dotyczącą ludzi i miejsc. Odwieczne są migracje w poszukiwaniu lepszych warunków życia i pracy, podróżowali studenci i uczeni, wędrowali rozmaici artyści, wróżbici. Znaczną rolę w przepływie ludzi i ich kultur odgrywał i odgrywa handel, współpraca w tworzeniu dóbr materialnych. Godnym podkreślenia zjawiskiem było sprowadzenie i osadzenie w granicach własnego państwa grup pożytecznych w rozwoju tego państwa - rzemieślników, kupców, artystów, uczonych itd. Powstawały społeczności i społeczeństwa wielokulturowe, w których żyli ludzie wywodzący się i/lub należący do różnych grup etnicznych, narodowych, ludzie różnych ras, kultur. Ważnym obszarem zróżnicowania były i pozostają wierzenia, wyznania, religie. W tak tworzących się społeczeństwach z większą lub mniejszą otwartością i intensywnością następuje wymiana idei, dóbr kultury duchowej i materialnej, powstają wartości wspólnotowe, kreowane wysiłkiem rozmaitych grup. Te obszary wielokulturowości od stuleci niosą sporo doświadczeń dobrych, sprzyjających pomyślnemu, szczęśliwemu życiu ludzi, ale niosą też niemało doświadczeń trudnych.

Przypomnienie tych znanych dróg kształtowania się społeczeństw wielokulturowych ważne jest z tego względu, że znajomość sposobu powstawania wielokulturowości i doświadczeń związanych z wielokulturowością pozwala lepiej zrozumieć wiele współczesnych zachowań. Społeczności tworzone w tak różny sposób miały różny stosunek do wspólnego życia - inne były i są relacje między zaborcami i podbitymi społecznościami, inne między partnerami handlowymi czy społecznościami współpracującymi w jakimś zakresie, a jeszcze inne między rdzennymi mieszkańcami a grupami zapraszającymi do osiedlania się i potrzebnymi w danym społeczeństwie. Te pierwotne czy dominujące przyczyny wielokulturowości wyznaczały i wyznaczają spostrzeganie zróżnicowania i relacji między ludźmi, między grupami większościowymi i mniejszościowymi oraz między ich kulturami. Historyczny przekaz pozytyw- 
nych lub negatywnych okoliczności, doświadczeń - przekaz dokonujący się m.in. w tradycji rodzimej, tradycji poszczególnych społeczności, w literaturze i sztuce, w pracach historycznych - tworzy „dobrą" lub „złą” tradycję i zazwyczaj nie pozostaje bez wpływu na współczesne relacje. Tradycje te wykorzystują - i w dobrych, i w złych intencjach - politycy, ludzie żądni władzy.

Wielokulturowość w potocznym, powszechnym rozumieniu kojarzy się głównie ze zróżnicowaniem narodowym i etnicznym. To rzeczywiście ważny wymiar wielokulturowości. Ale zjawisko to ma i inne - również istotne w życiu ludzi - wymiary. Do najważniejszych należy zróżnicowanie religijne czy wyznaniowe. Często zróżnicowanie narodowościowe czy etniczne pozostaje w wyraźnych związkach z wyznawaną religią, określonym wyznaniem, wierzeniami.

Współcześnie pojmowanie wielokulturowości dotyczy nie tylko spraw narodowości, etniczności, religii czy wyznań. Zgodnie z dosłownym odczytaniem tego pojęcia podkreśla się zróżnicowanie właśnie kultur - języków, obyczajów, stylów życia, tego wszystkiego, co składa się na kulturę duchową i materialną. Tak rozumiane zróżnicowanie kultur dotyczy także ludzi należących do tego samego narodu czy grupy etnicznej, wyznających tę samą religię. Nawet małe społeczności - lokalne, sąsiedzkie, uczniowskie, pracownicze - mogą być i często są wielokulturowe. Do takiego odczytania wielokulturowości skłaniają m.in. prace Michaiła Bachtina i czerpana z nich kategoria „pogranicza kultur”.

Powróćmy jednak do głównego wątku - zróżnicowania narodowego i etnicznego. Dzieje różnych społeczeństw i różne drogi kształtowania się współczesnych państw sprawiły, że wielonarodowe i wieloetniczne państwa są zjawiskiem powszechnym. Różna jest jednak skala zróżnicowań, rozmaite doświadczenia związane z tworzeniem organizmów państwowych. W rozważaniach o oświacie zagadnienia te traktowane są dość powierzchownie, a przecież bliższe wyobrażenie sobie skali i złożoności zróżnicowania społeczeństw jest ważnym czynnikiem wyznaczającym myślenie o edukacji w warunkach wielokulturowości. O rozmiarach zróżnicowania można dużo dowiedzieć się, sięgając do rzadko przywoływanych lub całkowicie pomijanych w rozważaniach pedagogicznych danych statystycznych. Przytoczmy tylko nieliczne, wybrane przykłady. Poza ilustracją skali opisywanego zjawiska skłaniają one do kilku spostrzeżeń ogólniejszej natury.

Wśród państw o wyraźnie zróżnicowanej strukturze narodowościowej i etnicznej można wyróżnić kilka grup. Jedna to nierzadko sztucznie utwo- 
rzone państwa - w dużej liczbie państwa afrykańskie - na terenach byłych kolonii. W granicach tych państw znalazły się społeczności często bardzo różne pod względem etnicznym i kulturowym. Przykładami są m.in. dwa państwa Kongo - Demokratyczna Republika Kongo (około 200 grup etnicznych - z grupą dominującą Bantu), Republika Kongo (Kongo 48\%, Sanqha 20\%, M’Bochi 12\%, Teke 17\%, Europejczycy i inni 3\%), Erytrea (dziewięć grup etnicznych - w tym Tigrinya 55\%, Tigre 30\%, Sako 4\%), Etiopia (Oromo 34,5\%, Amara 26,9\%, Somalia 6,2\%, Tigraway 6,1\% i in.), Kenia (Kikuyu $22 \%$, Luhya 14\%, Luo 13\%, Kalenjin 12\%, Kamba 11\% i in.), Nigeria (około 250 grup etnicznych), Rwanda (Hutu 84\%, Tutsi 15\%), wieloetniczne dwa państwa - Sudan i Sudan Południowy². Kolonialna spuścizna i sposób tworzenia tych państw zrodziły wiele konfliktów i wojen, niektóre wojny trwają nadal. Wielokulturowość zazwyczaj staje się czynnikiem wzmocnienia - niekiedy wywoływanych lub potęgowanych przez obce państwa, korporacje, lobby surowcowe i zbrojeniowe - waśni, kryzysów, wojen.

Inna odmiana wielokulturowości występuje w niektórych państwach Azji i Półwyspu Arabskiego. Zróżnicowanie narodowościowe i etniczne spowodowane tam jest przede wszystkim potrzebami rynku pracy. Taka sytuacja występuje np. w Bahrajnie (około 1/3 ludności to przybysze z innych państw), Kuwejcie (Kuwejtczycy stanowią 45\%, inni Arabowie 35\%, przybysze z Południowej Azji 9\%, z Iranu 4\%), Katarze (Arabowie 40\%, Hindusi 18\%, Pakistańczycy również 18\%, Irańczycy $10 \%$, inni 14\%) ${ }^{3}$. Dobrobyt rdzennych mieszkańców tych państw - bogatych głównie w złoża ropy naftowej w znacznym stopniu opiera się na pracy przybyszów. Napływowi pracownicy z trudem uzyskują pełne prawa obywatelskie i w dużej części funkcjonują na marginesie życia społecznego.

Jeszcze inna sytuacja charakterystyczna jest dla wielokulturowych społeczeństw Ameryki Północnej i Ameryki Południowej. W różnych proporcjach liczbowych społeczeństwa te składają się z ludności rdzennej, przybyszów z Europy i Afryki, a także z innych kontynentów, ponadto liczne grupy są - jak się je określa - mieszanką grup wcześniej wymienionych. W danych demograficznych podaje się często nie pochodzenie narodowe czy etniczne, ale wskazuje się na kolor skóry, mieszankę ras (biali, czarni, mulaci, mieszani itp.). W przypadku Kanady podaje się w statystykach kategorie Brytyjczy-

2 https:/www.cia.gov/library/publications/the-world-factbook/fields/2075.html (26.04.2012).

3 Tamże. 
ków - 28\%, Francuzów - 23\%, innych Europejczyków - 15\%, amerykańskich Indian - 2\%, Azjatów, Afrykańczyków, Arabów - 6\% oraz grupy mieszane $26 \%$. Zróżnicowanie państw i społeczeństw w tych częściach świata jest tak rozmaite, że trudno o jednoznaczne uogólnienia. Wielość ras, narodowości i kultur w większości traktuje się jako stan naturalny. Problemem pozostaje zróżnicowany status społeczny i materialny grup tworzących społeczeństwa. Czynnikiem ułatwiającym społeczną komunikację jest język hiszpański w Ameryce Południowej (poza Brazylią) i język angielski w Ameryce Północnej. Wciąż jednak są duże obszary wykluczenia społecznego i kulturowego.

Swoiste odmiany wielokulturowości występują w państwach azjatyckich, gdzie w różnych okolicznościach - w wyniku wojen, migracji, także kolonizacji, a potem dekolonizacji - ukształtowały się państwa wielonarodowe i wieloetniczne. Ich losy były i są bardzo różne. Ostatnio ta część świata wydaje się wyróżniać rozwojem gospodarczym i coraz silniejszym nastawieniem na współpracę regionalną i globalną. I tam jednak nie brak zadawnionych konfliktów na tle narodowościowym i etnicznym.

Tradycje wielokulturowości są wyraźne również w Europie. W poszczególnych państwach żyją różne grupy narodowe i etniczne, które łączy wiele dobrych doświadczeń i które nierzadko dzieli niemało tragicznych wydarzeń. Skala zróżnicowania narodowościowego w państwach na naszym kontynencie wydaje się relatywnie niezbyt duża. Obywatele innych narodowości - niż narodowość dominująca w danym państwie - są w państwach Unii Europejskiej grupą szacowaną na $5,3 \%^{4}$, a według innych danych na $6,4 \%$ - w sumie jest to około 31,9 mln osób - w tym 11,9 mln to obywatele innych państw UE . $^{5}$ Największy odsetek ludzi innej narodowości (aż 62,8\%) znajduje się w Luksemburgu ${ }^{6}$, państwie dość szczególnym m.in. ze względu na to, iż jest siedzibą wielu instytucji Unii Europejskiej, instytucji finansowych i handlowych. W UE problemy związane z wielonarodowością i tożsamością narodową występują głównie w państwach, które pozostawały przez lata pod dominacją Rosji i ZSRR. Tak jest w Estonii, gdzie dużą grupą są Rosjanie (25\% ludności) i na Łotwie (blisko $28 \%$ to Rosjanie). Inne powody - potrzeby rynku pracy, wieloletni proces migracji - sprawiły, że w Niemczech i w Austrii mieszka po około $10 \%$ ludności innej narodowości ${ }^{7}$. Skala zróżnicowania narodowościowo-et-

\footnotetext{
4. Eurostat - online data code:migr-pop1etz (26.04.2012).

5 Tamże.

6 DW.WORLD.EU (26.04.2012).

7 Tamże.
} 
nicznego i związane z tym konflikty pozostają wciąż silne w państwach poza UE - szczególnie na Bałkanach. Szacuje się np., że w Czarnogórze ludność tej narodowości to około 49\% mieszkańców, Serbowie 32\%, Bośniacy 8\%, Albańczycy $6 \%$, inni $12 \%$. W Macedonii tylko 64,2\% to Macedończycy, Albańczycy $25,2 \%$, Turcy $3,9 \%{ }^{8}$. Duże grupy mniejszości mieszkają w niedawno włączonej do UE Bułgarii. Mniejszości stanowią tam około 18\% ludności9.

W Polsce podstawowe mniejszości to - według deklaracji zgłoszonych w spisach ludności - osoby narodowości: niemieckiej około 147 tys. (niespełna 0,4\% ludności), ukraińskiej 27 tys. (0,07\%), litewskiej 5,6 tys., rosyjskiej, słowackiej, żydowskiej i czeskiej ${ }^{10}$. Ponadto są mniejszości etniczne: romska 12,7 tys., łemkowska 5,8 tys., tatarska i karaimska. Wyróżnia się także społeczność posługującą się językiem kaszubskim - ponad 52 tys. osób. Według danych GUS - mniejszości to około 306 tys. osób (0,8\% ludności) ${ }^{11}$.

Zgodnie z innymi danymi - opartymi na różnych źródłach, w tym szacunkach prowadzonych w toku badań naukowych - liczba osób zaliczanych do mniejszości jest znacznie większa. Uważa się, że np. Niemców jest 300-500 tys., Ukraińców i Białorusinów po 200-300 tys., Łemków 60-70 tys., Romów 20-30 tys., Litwinów 20-25 tys. ${ }^{12}$. Szacunki te w pewnej mierze oddają świadomość korzeni narodowych, tradycję rodzinną, bliskość danej kultury. Nawet przy takim podejściu do spraw tożsamości narodowej obywateli - zapewne zawyżającym szacunki - ogólna liczba osób kojarzonych z mniejszościami to około 2-3\% ludności Polski. Nowym zjawiskiem odnotowanym w oficjalnych spisach ludności jest identyfikacja śląska, którą deklaruje około 400 tys. osób ${ }^{13}$.

Najnowsze dane o charakterze oficjalnym - oparte na deklaracjach w spisie powszechnym z roku 2011 - różnią się od danych ze spisu przeprowadzonego w roku 2002. Według obliczeń GUS w ubiegłorocznym spisie - obok wskazań na narodowość polską (około 36,085 mln osób) - najwięcej osób zadeklarowało tożsamość śląską - było to około 809 tys. wskazań, a następnie

8 https:/www.cia.gov/library/publications/the-world-factbook/fields/2075.html (26.04.2012).

9 DW.WORLD.EU (26.04.2012).

10 Por. dane GUS.

11 Tamże.

12 J. Nikitorowicz: Edukacja regionalna i międzykulturowa. Warszawa 2009, WAiP.

13 Por. wyniki Spisu Powszechnego z 2011 roku. 
kaszubską - około 228 tys. Inne grupy mniejszościowe to: Niemcy - 109 tys., Ukraińcy -48 tys., Białorusini -47 tys., Romowie -16 tys., Rosjanie -13 tys., Amerykanie - 11 tys., Łemkowie - 10 tys., a także osoby deklarujące narodowość angielską - 10 tys. Pozostałe grupy mniejszościowe są mniej liczne (jeszcze nie podano dokładnych liczb) ${ }^{14}$.

Dodać należy, że w spisie z roku 2011 można było zadeklarować jednocześnie wybraną narodowość oraz przynależność do „innego narodu lub wspólnoty etnicznej”. W grupie wskazujących narodowość śląską (809 tys.) większość, bo około 415 tys. osób, połączyło ją z narodowością polską - podkreślając swoją, jak się to nazywa, podwojoną tożsamość. Pozostałe 362 tys. osób zadeklarowało narodowość śląską jako jedyną ${ }^{15}$.

Tożsamość kaszubską jako jedyną wskazało 16 tys. osób, a jako pierwszą 17 tys. osób. Dla większości Kaszubów ich tożsamość jest zarówno kaszubska, jak i polska.

Podwójne wybory - możliwe w najnowszym spisie powszechnym - ujawniły wskazywane w literaturze zjawisko kształtowania się lub trwania tożsamości wielowymiarowej obejmującej identyfikację z regionem lub wspólnotą etniczną, a jednocześnie z wybraną grupą narodowościową (a nierzadko również ze wspólnotami ponadnarodowymi czy ponadpaństwowymi - świadczą o tym podawane w różnych badaniach deklaracje, np. poczucie tożsamości europejskiej).

W opublikowanych dotąd danych zwraca uwagę znaczny wzrost deklaracji przynależności do narodowości ukraińskiej i rosyjskiej, a także pojawienie się sporych grup deklarujących narodowość amerykańską i angielską. Dostrzegalny jest spadek liczby osób deklarujących narodowość niemiecką.

Przyczyny zmian - w porównaniu z danymi z roku 2002 - są złożone i różnorodne. Deklaracje śląskości pojawiły się m.in. jako reakcja na niektóre niezręczne wypowiedzi polityków, ale również jako wyraz odradzającej się tożsamości śląskiej, echa publicznej dyskusji o kulturach regionalnych, narodowych i etnicznych, a zapewne także symptom poczucia swobody wyboru i deklarowania poczucia własnej tożsamości. Podobne czynniki w różnym stopniu mogły zaważyć na innych wyborach - np. tożsamości kaszubskiej. Deklaracje dotyczące narodowości - jak podano - amerykańskiej i angielskiej są prawdopodobnie w części konsekwencją migracji, mieszanych naro-

14 R. Jedlecki, K. Katka, J. Pszon: Ponad 800 tys. Ślazaków. „Gazeta Wyborcza” $\mathrm{z}$ dnia 23 marca 2012 roku.

15 Tamże. 
dowościowo rodzin, podwójnego obywatelstwa i innych uwarunkowań życia współczesnego społeczeństwa.

W przypadku osób deklarujących narodowość niemiecką spadek liczebności tej grupy tłumaczony jest m.in. tym, że spis nie objął wszystkich dorosłych mieszkańców Polski. Nie zostały jeszcze (do momentu powstania tego tekstu) podane oficjalne informacje o liczbie osób deklarujących inne - poza wymienionymi - narodowości lub przynależność etniczną. Dotyczy to m.in. osób narodowości litewskiej, a więc jednej z większych grup mniejszościowych.

Na głębsze analizy i interpretacje wyników spisu przyjdzie czas po opublikowaniu dokładnych danych. W tym miejscu sygnalizuję nasilanie się świadomości, iż tożsamość może mieć i ma często charakter wielowymiarowy - obejmujący różne identyfikacje (regionalne, etniczne, religijne czy wyznaniowe, obywatelskie, europejskie i inne).

Przytoczone dane ilustrują skalę wielokulturowości w wymiarze narodowym i etnicznym. Jednocześnie podkreślone zostały odmienne uwarunkowania zjawiska i relacje między społecznościami - swoiste odmiany wielokulturowości. Na te wymiary wielokulturowości nakładają się i czynią obraz jeszcze bardziej złożony sprawy religii, wyznań, wierzeń. Ponadto obraz ten komplikują inne różnice kulturowe, o których wspomniałem już wcześniej. Wszystko to silnie oddziałuje na myślenie o edukacji i na przyjmowane rozwiązania praktyczne w sferze edukacji.

Funkcjonowanie społeczeństw wielokulturowych można - w uproszczeniu - ująć w dwa powtarzające się scenariusze. Jeden - to zgodne życie ludzi i (bardziej lub mniej kooperacyjne) tworzenie dóbr duchowych i materialnych, stosunkowo bliskie kontakty, poznawanie i wzajemne wzbogacanie kultur. Ten scenariusz zazwyczaj powtarza się w czasach pokoju, czasach względnej stabilizacji lub poprawy warunków życia.

Drugi związany jest zazwyczaj albo z konfliktami wywoływanymi przez polityków, elity rządzące, ludzi żądnych władzy, „nawiedzonych” ideologów, albo z pojawiającymi się problemami gospodarczo-ekonomicznymi, kryzysami społecznymi, czasem drobnymi konfliktami, które - podsycane - przeradzają się w wielkie konflikty. W tym scenariuszu wrogami z reguły stają się Inni, Obcy.

Dzieje ludzkości przynoszą liczne przykłady przeplatania się tych scenariuszy. Czas zgodnego współistnienia i współpracy zakłócany jest przez ludzi żądnych władzy i zysku, przez silne grupy przemysłowe i wojskowe, 
czasem szalonych ideologów „naprawiających świat” (przeważnie przemocą). Tragiczne skutki ich działalności prowadzą ludzi do otrzeźwienia i powrotu czasu spokoju i pokoju. Aż do kolejnego - często specjalnie wywoływanego - konfliktu. Scenariusze powtarzają się - w różnym czasie i w różnych okolicznościach. Pamięć dawnych krzywd pozostaje pożywką nowych konfliktów i nowych krzywd. Wielokulturowość, która od wieków jest w czasach pokoju bogactwem społeczeństw i szansą rozwoju ludzi i kultur, staje się przyczyną, a często pretekstem, tragedii w czasach niepokojów.

Do wielu ważnych i błahych powodów (lub pretekstów) konfliktów we współczesnym świecie - od około dwustu lat - nader często dołącza się sprawy państwa narodowego. Idea państwa narodowego, łączona bądź z rewolucją francuską 1789, bądź z wojnami napoleońskimi czy późniejszymi ruchami niepodległościowymi w Europie, nadała pojęciu narodu (wcześniej kojarzonemu z rodem, plemieniem) nowe znaczenie. Od paru stuleci państwa narodowe są szansą rozwoju własnych narodów, ale też nieustannym polem konfliktów, wojen, prześladowania innych narodów i ich kultur. Zwolennicy „czystości” państw narodowych uczynili wiele złego w przeszłości, współcześni zwolennicy takich państw są zagrożeniem i dzisiaj. Wielokulturowość wykorzystywana bywa przez nich jako pretekst do waśni, konfliktów. Codziennie docierają o tym informacje ze świata. Postaw nacjonalistycznych, ksenofobii nie brakuje, niestety, i w Polsce.

Bogactwo zjawiska wielokulturowości i związane z różnymi odmianami wielokulturowości ideologie, motywacje, zachowania ludzi stanowią stałe tło i po części również treść edukacji. Szczególnie dotyczy to edukacji wielokulturowej, a tym bardziej międzykulturowej. Edukacja międzykulturowa zderza się z bagażem złych doświadczeń, stereotypów, pamięcią krzywd i lansowanymi od paru stuleci wyobrażeniami o patriotyzmie, tożsamości narodowej, państwach narodowych czy nawet narodowo-wyznaniowych bądź religijnych. O tym wszystkim należy pamiętać i zdawać sobie sprawę, że idea i praktyka edukacji międzykulturowej są wciąż nowością w życiu społecznym oraz że musi upłynąć wiele czasu i trzeba wiele trudu, aby społeczeństwa zrozumiały i zaakceptowały w praktyce przesłania i realizacje edukacji międzykulturowej. Szanse tej edukacji wydają się już teraz największe w tych państwach i społeczeństwach, które dążą do utworzenia i umocnienia struktur międzynarodowej współpracy, pokoju, zapewnienia praw człowieka i warunków rozwoju. Nadzieje na wykorzystanie tych szans, chociaż zapewne nie bez przeszkód, wiązać można m.in. z integracją europejską oraz miejscem i rolą Polski w pro- 
cesach integracyjnych. W zintegrowanych społeczeństwach państwowych i ponadpaństwowych, międzynarodowych, wielokulturowość jest i będzie docenianym i pielęgnowanym bogactwem tych społeczeństw i ich kultur.

\section{Oświata w warunkach wielokulturowości - doświadczenia edukacji wielokulturowej}

Oświata od dawna traktowana jest jako szczególne dobro, szansa rozwoju ludzi i postępu cywilizacyjnego, ale również jako obszar życia społecznego służący zdobywaniu i utrzymywaniu władzy, różnicowaniu możliwości awansu i wyznaczaniu dróg życiowych. W społeczeństwach wielokulturowych oświata zazwyczaj służyła utrzymaniu przewagi grup dominujących nad grupami zdominowanymi. Zagadnienia oświaty w społeczeństwach wielokulturowych nabrały wielkiego znaczenia w czasach, gdy nastąpiło upowszechnienie oświaty - najpierw przede wszystkim na poziomie elementarnym. Na gruncie europejskim proces upowszechniania oświaty szkolnej nastąpił bardzo wyraźnie w XVIII-wiecznych, a przede wszystkim w XIX-wiecznych monarchiach, w których żyły społeczności różnych narodowości i grup etnicznych. Wtedy formowało się wyobrażenie o oświacie dla grup mniejszościowych czy zdominowanych w granicach państw wielonarodowych. Europejskie wzory nie pozostawały bez wpływu na rozwiązania przyjmowane w innych częściach świata. Zazwyczaj oświata miała służyć utrzymaniu panującego ładu społecznego i wzmocnieniu grup dominujących. Na początku XX wieku podjęto próby określenia ideologii oświatowej odnoszącej się do grup mniejszościowych. Warto przypomnieć podstawowe elementy tej ideologii, a także przyjmowane koncepcje i realizacje edukacji wielokulturowej, które wyznaczyły teorię i praktykę edukacji w społeczeństwach wielonarodowych, wieloetnicznych, wielokulturowych. Przywołanie doświadczeń w tym zakresie wydaje się wskazane w tekście stanowiącym próbę podsumowania losów oświaty w społeczeństwach wielokulturowych. Dla znawców przedmiotu będzie to kolejna sposobność do refleksji nad dotychczasowymi - ogólnie mówiąc - modelami edukacji, a dla czytelników nowego periodyku, którzy nie zajmowali się dotąd kwestiami edukacji wielokulturowej, będzie to okazja do zapoznania się z wybranymi, jak się wydaje głównymi, sposobami pojmowania i prowadzenia tej edukacji.

W polskiej literaturze przedmiotu przywoływany jest wymowny przykład swoistej ideologii czy założeń oświaty dla grup mniejszościowych. Przykład 
ten odnosi się wprawdzie do grupy napływowej, ale grupy wywodzącej się z terenów znajdujących się pod zaborami, grupy żyjącej w państwie wielonarodowym. Oto w związku z obecnością w Niemczech (m.in. w Zagłębiu Ruhry) wielu polskich rodzin, które w ramach tzw. Ostflucktu (ucieczki siły roboczej z terenów wschodnich, z ziem rdzennie polskich) poszukiwały pracy w przemyśle i górnictwie, urzędnik oświatowy - Joseph Lichte - sformułował w roku 1901 podstawowe zadania szkoły w zakresie nauczania i wychowania dzieci obcojęzycznych (w istocie dzieci polskich z Zagłębia Ruhry i zaboru pruskiego). W tekście Lichtego „wskazane zostały trzy główne zadania stojące przed szkołą w związku z obecnością dzieci obcojęzycznych. Po pierwsze, chcąc zapewnić efektywną realizację celów nauczania, należy znacznie zmniejszyć liczebność klas szkolnych; po drugie, ponieważ ludność polska przysparza władzom niemieckim wielu kłopotów, należy przyznać priorytet nauczaniu w języku niemieckim ze szczególnym uwzględnieniem geografii i historii Niemiec; oraz po trzecie, na terenach zamieszkanych przez »wysoki procent elementu obcojęzycznego « należy zadbać o to, aby polskie dzieci przyswoiły sobie na całe życie »niemiecką istotę, niemieckie odczuwanie, myślenie i mowę«"16.

Oświata miała służyć w poszczególnych zaborach germanizacji lub rusyfikacji. Szkoła była instytucją spełniającą zadania asymilacji grup mniejszościowych. Ówczesne myślenie o edukacji w społeczeństwach/państwach wielonarodowych odnosiło się głównie właśnie do relacji między większościową (dominującą) grupą narodową a mniejszościową grupą narodową, słabszą (grupami mniejszościowymi, słabszymi). Edukacja miała służyć panowaniu nad społecznościami słabszymi (liczebnie niekiedy wcale nie mniejszościowymi) i asymilacji tych społeczeństw ${ }^{17}$.

16 M. S. Szymański: Od pedagogiki dla cudzoziemców do pedagogiki międzykulturowej w Republice Federalnej Niemiec, czyli modernizm i postmodernizm. W: J. Nikitorowicz (red.): Edukacja międzykulturowa: w kręgu potrzeb, oczekiwań $i$ stereotypów. Białystok 1995, „Trans Humana”, s. 91-92.

17 W tym i w następnym fragmencie tego artykułu odwołuję się m.in. do tekstów: W poszukiwaniu modelu edukacji międzykulturowej. W: T. Lewowicki, E. Ogrodzka-Mazur, A. Szczurek-Boruta (red.): Edukacja międzykulturowa w Polsce i na świecie. Katowice 2000, UŚ; Wielokulturowość i edukacja. Tradycje i meandry edukacji wielokulturowej. „Głos Nauczycielski” 2010, nr 38; Wielokulturowość i edukacja-perspektywa edukacji międzykulturowej. „Głos Nauczycielski” 2010, nr 39; Wielokulturowość i edukacja. „Ruch Pedagogiczny” 2010, nr 3-4; przytaczam fragment tekstu: Oświata $w$ warunkach wielokulturowości - od asymilacji do edukacji międzykulturowej $i$ wie- 
Różniły się sposoby asymilacji - od radykalnych, ograniczających lub nierespektujących praw grup mniejszościowych, do bardziej subtelnych - pozyskujących te grupy (ludzi z tych grup) na rzecz kultury i narodowości grupy dominującej. Przykłady różnego podejścia znamy m.in. z okresu zaborów.

Inny stosunek do wielokulturowości ukształtował się w Ameryce Północnej. Postępujący liberalizm oświatowy w USA dawał nieporównanie większe szanse podtrzymywania tożsamości grup mniejszościowych. Prawo i elementy wolnego rynku w oświacie umożliwiały istnienie różnych form edukacji wielokulturowej. Edukacja ta niewątpliwie sprzyjała adaptacji ludności napływowej do miejscowych warunków, w jakiejś mierze również służyła asymilacji. Oczywiście nie oznacza to, że w dziejach oświaty amerykańskiej nie było rozmaitych problemów, koncepcji i praktyk edukacyjnych, które w warunkach tamtejszej demokracji i modelu edukacji podważały sens i możliwość oświaty wielokulturowej. Doświadczyła tego znaczna część Afroamerykanów i Latynosów. Liberalizm oświatowy prowadzi zarówno do pozytywnych, jak i niekiedy do negatywnych skutków, które dotykają m.in. rozmaite grupy mniejszościowe. Jednym z takich skutków jest utrwalanie mechanizmu reprodukcji społecznej i stratyfikacji społecznej. Edukacja może odgrywać i odgrywa w tym niepoślednią rolę. Podobne doświadczenia były udziałem także społeczeństw zachodnioeuropejskich ${ }^{18}$.

To spojrzenie w przeszłość prowadzi do konstatacji, że działania, które kojarzyć możemy z edukacją wielokulturową, nacechowane były zazwyczaj podejściem hegemonistycznym i instrumentalnym. Elity władzy, grupy większościowe, instytucje państwowe wyznaczały pewien zakres swobód. Czyniły to pod wpływem rozmaitych okoliczności zewnętrznych i wewnętrznych, z mniejszą lub większą niechęcią, nieufnością. Niekiedy działania te miały charakter paternalistyczny - „dobra” władza (tak miała być postrzegana przez grupy mniejszościowe i/lub przez społeczność międzynarodową) udzielała pozwolenia na pewne formy aktywności służące podtrzymywaniu tożsamości grup mniejszościowych. Zazwyczaj jednak nadrzędnym celem była asymilacja albo przynajmniej utrzymanie spokoju społecznego, rzadko próby integracji społeczeństwa.

lowymiarowej tożsamości. W: W. G. Kremień, T. Lewowicki, J. Nikitorowicz, S. O. Sysojewa (red.): Edukacja w społeczeństwach wielokulturowych. Warszawa 2012, Wyższa Szkoła Pedagogiczna ZNP w Warszawie, Uniwersytet w Białymstoku.

18 B. Bernstein: Odtwarzanie kultury. Warszawa 1990, PIW; P. Bourdieu, J. C. Passeron: Reprodukcja. Warszawa 1990, PWN. 
Tragiczne doświadczenia z okresu wojny światowej skłaniały do poszukiwania nowych rozwiązań kwestii społecznych w państwach wielonarodowościowych, wieloetnicznych, a także w państwach, w których przejściowo znalazły się spore grupy obcokrajowców. Oto kilka przykładów.

W Republice Federalnej Niemiec dotkliwie odczuwany był brak siły roboczej, szczególnie robotników wykonujących ciężką i najgorzej płatną pracę. Kilka umów z państwami europejskimi stworzyło podstawy prawne napływu takiej taniej siły ${ }^{19}$. Na terenie RFN znalazło się wielu Greków, Hiszpanów, Jugosłowian, Turków i obywateli innych państw. Coraz większe znaczenie zyskiwała „pedagogika dla cudzoziemców”. Jej cele dotyczyły m.in. takich spraw, jak usuwanie deficytów w wykształceniu przybyszów, umożliwienie im nauki języka niemieckiego i ewentualne przyuczenie do zawodu, wreszcie chociażby częściowe włączenie ich do życia społecznego.

Wraz z upływem lat i zmianami warunków, a także ze wzrostem liczebności grup napływowych, kształtowały się różne koncepcje polityki społecznej i różne postawy wobec obcokrajowców. Najpierw traktowano ich jako przejściowo obecną w RFN siłę roboczą. Określano tę koncepcję hasłem „rotacji”. Później podjęto próby asymilacji czy też - jak nazywano ten proces - integracji, włączenia obcokrajowców w organizm społeczeństwa niemieckiego. Niewielkie sukcesy w tym zakresie oraz m.in. względy ekonomiczne, gospodarcze i demograficzne wywołały postawy „żądania powrotu” obcokrajowców do ich ojczyzn ${ }^{20}$.

Każdej z tych koncepcji i każdemu z lansowanych rozstrzygnięć w sferze praktyki społecznej towarzyszyły poczynania edukacyjne nastawione bądź na przygotowanie obcokrajowców do powrotu, bądź na sprzyjanie integracji (czy raczej asymilacji). Ambiwalentność i/lub zróżnicowanie postaw wobec kwestii cudzoziemców nie ułatwiały i chyba nadal nie ułatwiają rozwiązania problemów.

W państwach europejskich znane są też inne (niż niemieckie) sposoby postępowania. Oto np. we Francji, jednej z kolebek europejskich demokracji, od lat dominowało stanowisko, że wszyscy mieszkający tam ludzie są równi, a zatem nie ma mniejszości. Taka konstrukcja logiczno-prawna nie pozosta-

19 M. S. Szymański: Od pedagogiki dla cudzoziemców do pedagogiki międzykulturowej $w$ Republice Federalnej Niemiec, czyli modernizm i postmodernizm. W: J. Nikitorowicz (red.): Edukacja międzykulturowa: $w$ kręgu potrzeb, oczekiwań i stereotypów. cyt. wyd.

20 Tamże. 
wała bez wpływu na praktykę oświatową, ponieważ pozwalała obowiązek respektowania praw mniejszości do własnej oświaty zastąpić możliwością prowadzenia takiej oświaty ${ }^{21}$. Odbijało się to na stosunkowo niewielkiej ofercie dla (jakoby nieistniejących) grup mniejszościowych. Niedocenianie tych spraw i problemy społeczne potomków ludności napływowej (m.in. z byłych kolonii) powodują powtarzające się protesty, bunty, konflikty. Jednocześnie grupy te przejawiają coraz większą aktywność w organizowaniu stowarzyszeń i instytucji podtrzymujących ich kulturę.

Zdecydowanie bardziej przychylny klimat dla edukacji wielokulturowej panuje w Hiszpanii. W kraju tym konstytucja uznaje pluralizm kulturowy i językowy, dopuszcza szerokie możliwości nauczania języków mniejszościowych. Możliwości te są z powodzeniem wykorzystywane, o czym świadczy wzrost liczby uczniów pobierających naukę w języku hiszpańskim i języku innej (własnej) grupy. Swobody w edukacji językowej są tak duże, że zauważa się nawet wyraźne zagrożenie poczucia tożsamości narodowej i wspólnej kultury mieszkańców Hiszpanii ${ }^{22}$. Zagrożenie to występuje najsilniej w Katalonii i Kraju Basków. Problemem staje się nie asymilacja, lecz dezintegracja społeczeństwa, tendencje separatystyczne.

W innych państwach europejskich dostrzec można różne ujęcia edukacji wielokulturowej mieszczące się - najogólniej mówiąc - między modelem asymilacyjnym a modelem nieskrępowanego rozwoju kultur społeczności mniejszościowych. Standardy prawa międzynarodowego - w tym regulacje prawne Unii Europejskiej - mają chronić trwanie i rozwój tych kultur. W praktyce - jak wiadomo - bywa różnie.

W poszukiwaniu wzorów edukacji wielokulturowej i międzykulturowej sięga się do przykładów pozaeuropejskich, na przykład z USA. Dominująca tam ideologia społeczna i oświatowa przyjmuje współwystępowanie różnych narodowości, wierzeń, kultur, języków. Zgodnie z koncepcją „tygla” jako naturalne dopuszcza się nauczanie dwujęzyczne i wielokulturowość w edukacji. Podejmuje się rozmaite działania wspierające edukację wielokulturową, np. przygotowuje się dwujęzyczne programy nauczania, kształci nauczycieli posługujących się dwoma (albo kilkoma) językami. I tam jednak duże grupy (np.

21 W. Rabczuk: Polityka edukacyjna Unii Europejskiej wobec mniejszości narodowych i etnicznych. W: W. Rabczuk: Z problematyki pedagogiki porównawczej. Warszawa 1998, IBE.

22 Tamże. 
Latynosów) żyją „obok” społeczeństwa amerykańskiego. W amerykańskim "tyglu” kultur także bywa trudno z integracją.

Pouczające są doświadczenia w zakresie polityki narodowościowej i edukacji wielokulturowej w Australii. Przyjmowano tam m.in. koncepcję pluralizmu przejściowego i dwujęzyczności przejściowej, także monizmu hybrydalnego. W kształtowaniu się tamtejszego modelu edukacji wielokulturowej mieli udział Polacy - Jerzy Zubrzycki i Jerzy J. Smolicz ${ }^{23}$.

Edukacja wielokulturowa jest szansą na podtrzymywanie, pielęgnowanie i rozwój kultur różnych grup i kształtowanie się tożsamości grupowej. Daje także możliwość poznawania Innych i ich kultur. W praktyce edukacyjnej często jednak staje się polem zmagań grup mniejszościowych, które dążą do zachowania własnej kultury, z grupą większościową (politykami, władzami oświatowymi, różnymi grupami obywateli), która bardziej zainteresowana jest asymilacją mniejszości (rzadziej autentyczną integracją - z zachowaniem odrębności kultur).

Dotychczasowe dzieje edukacji wielokulturowej świadczą o tym, że edukacja podejmowana przez grupy mniejszościowe często dzieje się „obok” edukacji dominującej w danym państwie - i w opozycji lub w pewnej izolacji, z nieufnością i obawą wobec grupy większościowej. Dawne złe doświadczenia, ale także w niektórych państwach doświadczenia nowe, sprawiają, że edukacja podtrzymuje podziały, poczucie obcości, „bycie obok”. To znaczne ograniczenie sensu edukacji wielokulturowej, w ogóle edukacji ${ }^{24}$.

Nową perspektywę edukacyjną i szanse na zmianę tradycyjnych podejść do edukacji w warunkach wielokulturowości daje edukacja międzykulturowa. Jej przesłaniem jest otwarcie na kontakty z ludźmi z innych grup narodowościowych, etnicznych, wyznaniowych, kulturowych. Ważne jest poznawanie Innych i ich kultur, wspólne poczynania kulturalne i oświatowe, wzajemne wzbogacanie kultur przez przyjmowanie i oferowanie tego, co w danych kulturach najbardziej wartościowe, przełamywanie stereotypów, kształtowanie poczucia ludzkich wspólnot, integracja.

W otwartych na świat, demokratycznych społeczeństwach wielokulturowych sprawy te są coraz lepiej rozumiane i znajdują praktyczne odzwierciedlenie w edukacji i kulturze. W przypadku edukacji odzwierciedla się to

23 J. J. Smolicz: Kultura i nauczanie w społeczeństwie wieloetnicznym. Warszawa 1990, PWN i inne.

24 Por.: T. Lewowicki, E. Ogrodzka-Mazur, A. Szczurek-Boruta (red.): Edukacja międzykulturowa $w$ Polsce i na świecie. cyt. wyd. 
w treściach kształcenia i wychowania, współpracy szkół i innych instytucji oświatowych z placówkami zagranicznymi, w zorganizowanych wyjazdach edukacyjnych uczniów, studentów, nauczycieli, organizatorów oświaty, współdziałaniu stowarzyszeń kulturalnych różnych narodowości i grup etnicznych, współdziałaniu organizacji wyznaniowych itp. Coraz więcej takich poczynań podejmowanych jest w Polsce oraz w ramach współpracy środowisk polskich ze środowiskami zagranicznymi. Dotychczasowe doświadczenia w tym zakresie budzą optymizm i skłaniają do większej aktywności edukacyjnej i - szerzej - społecznej.

Idea i praktyka edukacji międzykulturowej godne są szczególnego poparcia, jeżeli rzeczywiście pragniemy czynić świat lepszym, pomóc ludziom w szczęśliwym życiu - bez wojen, wrogości, zapiekłych i nieracjonalnych konfliktów wywoływanych zróżnicowaniem kulturowym, religijnym i wieloma innymi - jakże często bezsensownymi i wyniszczającymi - podziałami między ludźmi. Politycy nader rzadko zdają sobie sprawę, że ich powinnością są starania o szczęście ludzi. Przypominają o tym filozofowie, pedagodzy. Oto mamy sposobność przyczynienia się do tego, by cel taki osiągnąć. Świadomość trudności, konieczność ciągłych zmagań ze złożonością sytuacji społecznych, z uprzedzeniami, postawami zachowawczymi nie powinny nas zniechęcać, lecz przeciwnie - mobilizować do działań. Powinnością pedagogów, wychowawców jest pomaganie ludziom w wydobywaniu z nich tego wszystkiego, co w nich najlepsze. Edukacja międzykulturowa jest w tym szlachetnym dziele ważnym sposobem postępowania i drogą spełniania się nadziei na lepszy świat, na szczęśliwe życie ludzi.

\section{Oświata wobec kwestii tożsamości}

Oświata od wieków jest istotnym czynnikiem kształtowania tożsamości. W dziejach nowożytnych społeczeństw szczególną rolę oświaty wiązano i wiąże się z kształtowaniem tożsamości narodowej, kształtowaniem poczucia świadomości i identyfikacji z określoną grupą narodową i kulturą tej grupy. Przypomnieć warto, że współcześnie pojmowana świadomość narodowa i państwowa krystalizowała się przede wszystkim w wieku XIX. Wtedy to kolejne fale ruchów niepodległościowych, silne tendencje emancypacyjne, zmiany gospodarcze i społeczne, wojny napoleońskie, ruchy rewolucyjne z przełomu drugiego i trzeciego dziesięciolecia, Wiosna Ludów, wspomniane już uprzednio przejawy liberalizacji w sprawach oświaty - nadały nowe zna- 
czenie sprawom tożsamości narodowej, kulturze i językom grup narodowych. Kultura i oświata uwzględniające elementy narodowe czy narodowościowe stały się ważnymi kwestiami społecznymi i istotnymi problemami politycznymi. Wiek XIX stał się czasem zmagań o powstanie państw narodowych. Z czasem powstały takie państwa (mające wówczas niekiedy krótką historię). Sprawy odrębności historii, języka, kultury coraz silniej wyznaczały myślenie i działania związane z dążeniami do powołania państw narodowych. Oświata zaczęła pełnić ważną rolę w kształtowaniu świadomości narodowej i narodowo-państwowej identyfikacji.

W wielkich monarchiach wielonarodowych ujawniały się różne formy ruchów niepodległościowych, które również odwoływały się do historii, kultury, języka poszczególnych narodów. W niektórych monarchiach (np. austrowęgierskiej) zaczęto nawiązywać do kultur i języków społeczeństw zależnych. W innych - jak w Prusach i w Rosji - tępiono inne kultury. Oświata służyć miała narzucaniu kultury grupy dominującej innym grupom. W wyniku asymilacji narody podbite miały przyjmować tożsamość kulturową - a z czasem narodową - narodu dominującego.

W różnych warunkach i z odmiennymi intencjami zarówno w powstających państwach narodowych, jak i w wielonarodowych monarchiach, przyjęto modele edukacji prowadzącej do kształtowania jednoznacznych tożsamości narodowo-państwowych. W jednym przypadku podyktowane to było dążeniem do obrony tożsamości własnego narodu i jego państwa, w drugim do narzucenia własnego modelu tożsamości i podporządkowania Innych w oczywistym zamiarze utrzymania państwa wielonarodowego (z dominacją jednego narodu).

Modelowi (modelom) edukacji narodowo-państwowej często towarzyszyły elementy religii czy wyznania (wyznań). W warunkach odwiecznego hierarchicznego ładu społecznego ${ }^{25}$ wychowanie religijne było ważnym czynnikiem stabilizacji tego ładu. Oprócz wychowania religijnego wykorzystywane były odwołania do - jak nazwalibyśmy to dzisiaj - wychowania regionalnego, które od poznania „małej Ojczyzny” prowadzić miało do identyfikacji z „dużą” narodową Ojczyzną. Edukacja regionalna również współcześnie traktowana jest jako istotny element wychowania patriotycznego. Wydaje się jednak, że odwołania regionalne spełniały i spełniają w dużej mierze charakter instrumentalny - miały i mają być etapem i służyć wychowaniu narodowo-państwowemu, nazywanemu patriotycznym, albo - myląco - obywatelskim.

25 T. Lewowicki: Przemiany oświaty. Warszawa 1994, UW. 
Taki (może nieco przejaskrawiony, a może wcale nie) obraz tożsamości i roli oświaty w jej formowaniu zawładnął myśleniem Europejczyków od około dwustu lat. Tyle - z grubsza rzecz ujmując - trwa dominujące wyobrażenie o państwie, państwie o charakterze narodowym. Wiek XX przyniósł tragiczne skutki praktycznych doświadczeń we wdrażaniu „modelu” państw narodowych. Narodowe elementy w refleksji i praktyce odnoszącej się do rozumienia i funkcjonowania państw nadal wydają się najważniejsze, traktowane są jako oczywiste i obowiązujące. Szczególnie wygodne pozostają dla wielu polityków, którzy na narodowo-państwowym stereotypie życia budują swój kapitał, swoją pozycję. Ujawniają się stare i nowe oblicza nacjonalizmów, ksenofobia, wrogość do Innych. Co pewien czas na tym tle wybuchają konflikty, wojny. Tragiczne wydarzenia nękają przede wszystkim ludność innych kontynentów, ale nie omijają też Europy.

Pewne nadzieje na łagodzenie napięć wiązano z edukacją wielokulturową. Edukacja ta - jak okazało się w wielu państwach - nie przełamuje jednak podziałów narodowościowych, a często je wzmacnia. Poprawność polityczna i respektowanie praw do własnej oświaty i kultury okazuje się w przypadku edukacji wielokulturowej zabiegiem sprzyjającym stygmatyzacji, różnym formom izolacji, a w konsekwencji nierzadko wykluczeniu społeczności mniejszościowych. Z pewną dozą przesady można uznać, że zarówno grupa większościowa, jak i grupy mniejszości wciąż odwołują się do wzorów edukacji podtrzymującej tradycyjne modele tożsamości narodowej, tożsamości kulturowej.

Jednocześnie na naszym kontynencie dostrzec można symptomy krytyki opisanego modelu państwa narodowego - wzorowanego na wyobrażeniach sprzed dwustu czy stu lat. Inaczej widzi się dziś sprawy tożsamości, w tym także tożsamości narodowej i państwowej. Przede wszystkim - w społeczeństwach demokratycznych, w których ludzie są wolni i mogą współdecydować o swoim losie, dostrzega się ograniczenia związane z traktowaniem tożsamości jako sfery dziedziczonej i/lub nadanej. Ludzie mają prawo wybierania i decydowania także w sprawach własnej tożsamości. Myślenie plemienne, osobliwa ortodoksja, która wyklucza każdego, kto sprzymierzył się (np. założył rodzinę) z kimś z innego „plemienia”, staje się szkodliwym anachronizmem. W coraz bardziej integrującym się społeczeństwie europejskim przede wszystkim Unii Europejskiej - dokonują się w masowej skali procesy migracji, ludzie różnych narodowości uczą się, pracują, przyjaźnią, żenią i wychodzą za mąż, wybierają obywatelstwa. To niejako naturalne zjawiska, 
które w niektórych grupach społecznych zachodziły i dawniej, ale teraz stają się udziałem wielu współczesnych ludzi.

Podkreślić należy, że świadomość pochodzenia, urodzenie w rodzinie określonej narodowości czy o określonym wyznaniu (religii) są ważnymi elementami określania tożsamości. To zrozumiałe. Wszystkie te fakty nie muszą jednak przesądzać o tożsamości, a przede wszystkim o poczuciu tożsamości jednostki. Powtórzyć trzeba, że tożsamość nie musi być nadana czy dziedziczona. Ludzie i dawniej dokonywali wyborów - religii, obywatelstwa, nawet narodowości. Wybory takie były jednak zazwyczaj przez grupy, z których wywodziła się jednostka, uważane za zdradę, za czyn godny potępienia, jeżeli ktoś wybierał inaczej niż „jego” otoczenie, rodzina, społeczność. Ten sposób myślenia i reagowania na wybory tożsamościowe nie musi i nie powinien dominować.

Nowe podejście do spraw (samo)identyfikacji, tożsamości budzi często sprzeciw. Dzieje się tak przeważnie w społecznościach, które czują się zagrożone lub z jakiegoś powodu tworzą lub odzyskują wszystkie elementy własnej tożsamości grupowej - własną historię, terytorium, język i kulturę, organizację życia społecznego, państwowość i inne ${ }^{26}$. W takiej sytuacji są w świecie liczne społeczeństwa. Również w Europie w wielu państwach (m.in. powstałych po upadku Związku Radzieckiego, także państwach powstałych po rozpadzie Jugosławii) odradza się tożsamość państwowa. Wszędzie tam raczej nie ma zrozumienia i akceptacji swobody wyborów tożsamościowych. Tłumaczy to m.in. Teoria Zachowań Tożsamościowych ${ }^{27}$. Dąży się do swoistego ujednolicenia tożsamości - wprowadzenia jednego języka urzędowego, określenia rygorystycznych warunków uzyskania obywatelstwa, bardziej lub mniej wyrazistego marginalizowania oświaty i kultury mniejszości narodowych i etnicznych. Stałym wątkiem jest poczucie zagrożenia ze strony Innych, obawa przed silną kulturą Innych. Jaskrawe przykłady występują m.in.

26 T. Lewowicki: Problemy tożsamości narodowej - w poszukiwaniu sposobów uogólnionych ujęć kwestii poczucia tożsamości i zachowań z tym poczuciem związanych. W: M. Urlińska (red.): Edukacja i tożsamość etniczna. Toruń 1995, UMK; tenże: Szkic do teorii zachowań tożsamościowych. W: T. Lewowicki, E. Ogrodzka-Mazur (red.): W poszukiwaniu teorii przydatnych w badaniach międzykulturowych. Cieszyn 2001, UŚ - Filia w Cieszynie.

27 Tamże oraz T. Lewowicki: O badaniach społeczności pogranicza - od parcjalnych opisów ku elementom teorii zachowań tożsamościowych. W: J. Nikitorowicz (red.): Edukacja międzykulturowa: w kręgu potrzeb, oczekiwań i stereotypów. Białystok 1995, „Trans Humana”. 
w państwach niedawno zintegrowanych z Unią Europejską - Litwie, Łotwie, Estonii. Zapewne z podobnymi problemami przyjdzie zmierzyć się również Ukrainie, w której dużą grupę stanowią Rosjanie, silną pozycję ma język rosyjski i rosyjskojęzyczna kultura.

Stosunek do edukacji w społeczeństwach wielokulturowych oraz spraw tożsamości jest silnie wyznaczany przez historię, losy różnych narodów i ich państw, poziom rozwoju społecznego i gospodarczego, zakres i charakter powiązań z innymi narodami i państwami, aktualny poziom integracji międzynarodowej. Sprawia to, że - uogólniając - można dziś mówić o dwóch typowych postawach.

Jedna to nawiązująca do wspomnianej dwustuletniej tradycji państw narodowych dość ortodoksyjna postawa narodowo-państwowa. Wzorem są modele czerpane z przeszłości. Znajdują one uznanie - powtórzyć to wypada - przede wszystkim w społeczeństwach odczuwających zagrożenie swojej tożsamości zbiorowej, często dotkliwie doświadczonych przez inne społeczeństwa (narody, państwa), odzyskujących własną tożsamość lub ją tworzących. W warstwie oficjalnej w życiu społecznym zwolennicy tej postawy odwołują się do haseł suwerenności, patriotyzmu, narodowo-państwowej "racji stanu”. Bardzo często jednak pożywką są rozmaite odmiany ruchów nacjonalistycznych, ksenofobia, niechęć lub wrogość wobec Innych. Takie postawy są dobrze znane (także ich przejawy na gruncie edukacji), znane też są skutki ich przyjmowania.

Druga przejawia się w dążeniu do kooperacji, integracji, wspólnego kształtowania - w wymiarze międzynarodowym, międzypaństwowym - bezpieczeństwa, warunków współpracy, wspierania rozwoju stowarzyszonych państw i społeczeństw. W warunkach integracji europejskiej (w niektórych obszarach - globalizacji) jest to droga do pokojowego, pomyślnego rozwoju, wzajemnego wspierania się i wspólnej dbałości o bezpieczeństwo, warunki życia, kulturę - zapewniane m.in. dzięki integracji politycznej, gospodarczej i obronnej. Rozumie to duża część społeczeństw Unii Europejskiej. Znajduje to odbicie w edukacji.

Przyszłość Europy w znacznej mierze zależeć będzie od tego, która z tych postaw zdominuje życie społeczeństw na naszym kontynencie.

Istotną zmianą w ujmowaniu tożsamości ludzi jest uznanie wielowymiarowości tożsamości. Świadomość własnej tożsamości dotyczy różnych płaszczyzn czy obszarów - rodzinnego, lokalnego, regionalnego, „małej Ojczyzny”, narodowego czy etnicznego, państwowego/obywatelskiego, religijnego czy 
wyznaniowego, kulturowego, a coraz częściej także europejskiego, a może nawet globalnego. Każdy człowiek kształtuje - także pod wpływem środowiska społecznego, edukacji, doświadczeń - swoje własne poczucie tożsamości zawierające różne elementy składowe, różne wymiary ${ }^{28}$. Tożsamość kształtuje się i zmienia pod wpływem wiedzy, przeżyć, życiowych doświadczeń. Formowanie się tożsamości, poczucia tożsamości jest skomplikowanym procesem stawania się i uświadamiania własnego Ja (w relacjach z Innymi, światem kultury, przyrodą, światem idei i rzeczy). W takiej wielowymiarowej tożsamości mogą być ważne i są ważne różne jej wymiary, różne obszary. Nie ogranicza się poczucia tożsamości do jednego czy paru wybranych wymiarów - narodowego czy wyznaniowego.

W społeczeństwie danego państwa szczególnie ważne staje się poczucie obywatelstwa, bycie obywatelem - bez względu na narodowość, religię, związki społeczne, identyfikację z regionem itd. Śmiałym projektem w państwach Unii Europejskiej mogą być wizje jeszcze większej integracji, Federacja Europejska czy nawet Stany Zjednoczone Europy. Takie projekty wyznaczają perspektywę obywatelstwa europejskiego w nowym wymiarze. Oby projekty takie powiodły się i objęły możliwie wiele społeczeństw. Przygotować do tego w znacznej mierze powinna edukacja - pozwalająca lepiej zrozumieć i zaakceptować nowe pojmowanie tożsamości indywidualnej i zbiorowej (społecznej) - w wielu wymiarach tożsamości, edukacja prowadzona z przesłaniem uniwersalnych wartości wyznaczających postępowanie ludzi. Takiej edukacji i - w konsekwencji - szczęśliwemu życiu ludzi służy m.in. edukacja międzykulturowa. Powodzenie zależeć będzie jednak od współdziałania wielu podmiotów życia społecznego - kształtujących warunki rozwoju jednostki i społeczeństw, kreujących strategie przemian i tworzących podstawy szeroko pojmowanej edukacji społecznej. Impulsy do refleksji i działania mogą i powinny płynąć ze świata elit intelektualnych, nauki, edukacji i kultury. W społeczeństwach wiedzy te właśnie środowiska mają szansę i po-

28 T. Lewowicki, E. Ogrodzka-Mazur, A. Szczurek-Boruta (red.): Edukacja międzykulturowa - dokonania, problemy, perspektywy. Cieszyn - Warszawa - Toruń 2011, Wydział Etnologii i Nauk o Edukacji, Uniwersytet Śląski w Katowicach, Wyższa Szkoła Pedagogiczna ZNP w Warszawie, Wydawnictwo Adam Marszałek; J. Nikitorowicz: Koncepcja tożsamości międzykulturowej w społeczeństwie wielokulturowym. W: J. Gajda, J. Izdebska (red.): Kultura - wartości - ksztatcenie wobec wyzwań $i$ zagrożeń XXI wieku. Suwałki 2004, Wyższa Szkoła Suwalsko-Mazurska im. Papieża Jana Pawła II; tenże: Kreowanie tożsamości dziecka. Wyzwania edukacji międzykulturowej. Gdańsk 2005, GWP; tenże: Edukacja regionalna i międzykulturowa. cyt. wyd. 
winność odegrania roli elit społecznego zaufania i elit współwyznaczających strategie rozwoju.

\section{$O$ rodzimej pedagogice międzykulturowej - jako (sub)dyscyplinie nauk pedagogicznych}

Niezwykle ważnym bodźcem do rozwoju edukacji wielo- i międzykulturowej w polskich uczelniach jest powstanie i działalność kilkunastu ośrodków prowadzących studia i badania dotyczące wielokulturowości i edukacji w społecznościach wielokulturowych. Do bardzo prężnych należą przede wszystkim uniwersyteckie ośrodki (zakłady, katedry, studia) w Białymstoku, Cieszynie, Krakowie, Warszawie, a także w Gdańsku, Opolu, Toruniu. Badania międzykulturowe prowadzone są również w Bydgoszczy, Poznaniu, Zielonej Górze. W tym opracowaniu największą uwagę zwrócić wypada na prace prowadzone w ośrodku cieszyńskim.

O rozległości tematyki badawczej podejmowanej przez cieszyńskie środowisko Uniwersytetu Śląskiego świadczą m.in. publikacje - w tym 48 tomów z serii „Edukacja Międzykulturowa” i liczne artykuły, komunikaty z badań. Formą wymiany doświadczeń i upowszechniania edukacji międzykulturowej były i są liczne konferencje, staże naukowe. Realizowanych było kilka grantów, realizacja kilku grantów - w tym międzynarodowych - trwa.

W kilku uczelniach - również w cieszyńskim wydziale UŚ - prowadzone są zajęcia dydaktyczne z zakresu edukacji wielo- i międzykulturowej. Odbywają się praktyki studenckie dotyczące tej edukacji, działają koła naukowe (w Cieszynie - Koło Naukowe Edukacji Międzykulturowej). Zagadnieniom wielokulturowości i edukacji międzykulturowej poświęcone są liczne prace licencjackie i magisterskie.

Wszystko to stanowi dobrą podstawę rozwoju edukacji międzykulturowej. Zagadnienia tej edukacji stają się ważnym nurtem badań pedagogicznych i oświatowych. Absolwenci studiów przenoszą idee i praktyczne propozycje do różnych środowisk - w tym do szkół i innych instytucji oświatowych.

Doświadczenia edukacyjne i dorobek naukowy środowisk zajmujących się edukacją międzykulturową skłaniają do sformułowania poglądu, że dokonania te mogą stanowić podstawę do opracowania syntezy zawierającej zarys pedagogiki międzykulturowej - jako dyscypliny nauk pedagogicznych. W odróżnieniu od wcześniejszych przykładów posługiwania się nazwą pe- 
dagogiki międzykulturowej (w literaturze niemiecko- i angielskojęzycznej) ${ }^{29}$, kiedy nazwą tą obejmowano niektóre wersje edukacji wielokulturowej i/lub brano pod uwagę tylko niektóre zagadnienia właściwe dyscyplinom naukowym, w ujęciu możliwym do spożytkowania współcześnie jest miejsce na wszystkie podstawowe składniki dyscypliny naukowej i uwarunkowania żywotności dyscypliny. Wymieniam je niżej ${ }^{30}$.

- Klarownie zarysowana koncepcja edukacji międzykulturowej i dotyczącego tego obszaru edukacji rozumienia pedagogiki. Na lansowane w pracach z zakresu edukacji międzykulturowej ujęcia zagadnień składa się spójny zespół poglądów i przekonań, które wyznaczają refleksję i działania dotyczące edukacji międzykulturowej. Odwołując się do definicji autorstwa L. Kohlberga i R. Mayer ${ }^{31}$, można przyjąć, że mamy do czynienia z czytelną ideologią pedagogiki międzykulturowej.

- W ramach refleksji i praktyki edukacyjnej używany jest stosunkowo precyzyjnie określony język, inaczej mówiąc - sieć pojęć. Część pojęć - jak zwykle w humanistyce - zaczerpnięta została z innych dyscyplin, część ma nadane znaczenie właściwe edukacji i pedagogice międzykulturowej.

- Również dość wyraźnie określony został obszar zainteresowań, pola i przedmioty badań. Znajduje to odzwierciedlenie w licznych publikacjach. Podkreślić przy tym należy interdyscyplinarność pedagogiki międzykulturowej.

- Odwołując się do pokrewnych dyscyplin humanistyki korzysta się z szerokiego zakresu metod, technik i narzędzi badań - zarówno badań ilościowych, jak i jakościowych. Zgromadzony został duży zasób wyników badań.

- Poczynania badawcze i strukturalne ukierunkowane są licznymi teoriami z zakresu nauk społecznych. Pedagogika międzykulturowa dysponuje - co wydaje się zjawiskiem nieczęstym w pedagogice - własnymi oryginalnymi propozycjami teoretycznymi, przykładem są Teoria

29 Por.: T. Lewowicki, E. Ogrodzka-Mazur, A. Szczurek-Boruta (red.): Edukacja międzykulturowa $w$ Polsce i na świecie. cyt. wyd.

30 Przywołuję tu fragment tekstu z artykułu: O doświadczeniach edukacji międzykulturowej i perspektywie edukacji i pedagogiki międzykulturowej. W: T. Lewowicki, E. Ogrodzka-Mazur, A. Szczurek-Boruta (red.): Edukacja międzykulturowa - dokonania, problemy, perspektywy. cyt. wyd.

31 L. Kohlberg, R. Mayer: Rozwój jako cel wychowania. W: Z. Kwieciński, L. Witkowski (red.): Spory o edukację. Warszawa 1993, IBE. 
Zachowań Tożsamościowych mojego autorstwa i Koncepcja kształtowania tożsamości - według J. Nikitorowicza. Propozycje te znalazły zastosowanie już w wielu badaniach, posłużyły do konstruowania metodologii badań, zostały wykorzystane przy interpretacjach wyników.

- Historyczny i współczesny dorobek edukacji wielokulturowej i edukacji międzykulturowej ma ujęcia porównawcze i ujęcia stanowiące syntezy wcześniejszych dokonań. Pedagogika międzykulturowa ma swoje korzenie, dzieje i całościowe przedstawienia wcześniejszych etapów. Można powiedzieć, że - zgodnie z dobrą tradycją humanistyki - ma pamięć o dorobku poprzednich pokoleń i poddaje ten dorobek krytycznej analizie.

- Godna uwagi jest kondycja kadrowa społeczności zajmujących się edukacją i w istocie pedagogiką międzykulturową. Liczba badaczy, rozwój naukowy, poziom prac uzasadniają przekonanie, że sytuacja kadrowa bardzo dobrze rokuje dyscyplinie naukowej. W mijających paru dekadach powstało dużo wartościowych publikacji. Pojawiają się nowe kierunki studiów i badań.

- Środowisko uprawiające pedagogikę międzykulturową jest już dość dobrze zorganizowane instytucjonalnie. Wielkim walorem pozostaje integracja i ścisła współpraca badaczy z wielu ośrodków akademickich. Wskazać należy na tradycje wspólnych działań w Społecznym Zespole Badań Kultury i Oświaty Pogranicza, potem w ramach Zespołu Pedagogiki Kultury i Edukacji Międzykulturowej pod patronatem KNP PAN, a teraz Stowarzyszenia Wspierania Edukacji Międzykulturowej.

- Wyraźne i wielostronne są powiązania teorii (teoretyków i badaczy) z praktyką oświatową. Pedagogika międzykulturowa spełnia funkcje właściwe naukom, które generują różne zastosowania praktyczne. Potrzeby społeczne wydają się mocno oddziaływać na żywotność - zakres, kierunki i metody badań - pedagogiki międzykulturowej.

\section{Tendencje zmian - nowe jakości w życiu społecznym i edukacji? (próba podsumowania)}

Przedstawione zjawiska można odczytywać jako symptomy ważnych zmian w spostrzeganiu wielokulturowości i edukacji w społeczeństwach wielokulturowych. Zmiany te następują (chociaż dzieje się to nie bez oporu) przede wszystkim w Europie, a najwyraźniej w państwach Unii Europejskiej. Na 
naszym kontynencie - w większości już od blisko 70 lat wolnym od wojen - bardziej niż w innych regionach czy częściach świata dostrzec można coraz odważniejsze próby zerwania $\mathrm{z}$ dotychczasowymi schematami myślenia o społeczeństwach wielokulturowych. Coraz częstsze są też próby nowego, sprzyjającego zgodnemu i pomyślnemu życiu ludzi, myślenia i działania dotyczącego edukacji.

Pierwszym obszarem zmian jest stosunek do wielokulturowości. Wprawdzie niektórzy politycy i przeważnie radykalne grupy zwolenników państw narodowych wieszczą kryzys wielokulturowości, ale coraz szerzej przyjmowany jest pogląd, że wielokulturowość stała się zjawiskiem niemal powszechnym i stanem niejako naturalnym. W demokratycznych społeczeństwach i państwach europejskich różne odmiany wielokulturowości po części mają odwieczną tradycję, po części są doświadczeniem minionego półwiecza. Wielokulturowość przyniosła wiele pożytku, jest traktowana jako bogactwo, jako szansa rozwoju ludzi i ich kultur. Wywoływanie konfliktów, rozbudzenie niechęci, a bywa że wrogości, wobec Innych, Obcych - zachowania występujące w okresach rozmaitych trudności (przeważnie gospodarczo-ekonomicznych) lub zachowania dyktowane często względami ideologicznymi czy światopoglądowymi, religijnymi nie przynoszą ani pożytku, ani chluby, stanowią wyraz nietolerancji, nierzadko ksenofobii, nacjonalizmu, nawet rasizmu. To raczej przejawy kryzysu wartości, kryzysu moralnego tych, którzy domagają się homogeniczności społeczeństw i kultur, a nie kryzys wielokulturowości. W życiu społeczeństw europejskich coraz więcej jest przejawów świadczących o zrozumieniu tych spraw i akceptacji europejskiej wielokulturowości.

Kształtowanie się nowoczesnego europejskiego społeczeństwa wielokulturowego przebiega i przebiegać będzie w ciągłych zmaganiach z utrwalonymi stereotypami, ambicjami polityków i ideologów, „złą pamięcią” dawnych doświadczeń. Procesom integracyjnym towarzyszą inicjatywy dezintegracyjne, separatystyczne, izolacjonistyczne. Jeśli dotyczą one spraw tożsamości kulturowej, to i one mogą i zapewne będą wzbogacać społeczeństwa europejskie. Rzecz w tym, by nie prowadziły do bezsensownych i szkodliwych podziałów, bo jaką przyszłość miałyby samodzielna Szkocja, a może i Walia, dwa państwa wyodrębnione ze współczesnej Belgii, kilka państw wyodrębnionych z Hiszpanii itd. Europa małych księstw, a tym bardziej jednolitych kulturowo, narodowościowo czy wyznaniowo państw, to nie jest wzór do naśladowania dzisiaj. Ale tendencjom integracyjnym przeciwdziałają tendencje przeciwne - należy o tym pamiętać i w edukacji przekazywać wiedzę o doświadczeniach 
z przeszłości, wiedzę o najnowszych dokonaniach i prawdopodobnych skutkach różnych scenariuszy przyszłości.

Drugi obszar zmian dotyczy edukacji w społeczeństwach wielokulturowych. Również w tym zakresie niełatwo będzie naruszyć utrwalone od lat struktury, ale coraz wyraźniej rysuje się obraz dysfunkcji szkolnictwa powielającego tradycyjny model edukacji wielokulturowej. Edukacja ta - powtórzyć to należy - w wielu przypadkach nie musi pełnić zadań oblężonych twierdz, placówek głównie broniących języka, kultury, tożsamości narodowej, ale stanowiących jednocześnie instytucjonalną formę stygmatyzacji, pogłębiania podziałów, podtrzymywania stereotypów, ortodoksyjnego patriotyzmu. Edukacja wielokulturowa prowadzona przez różne społeczności „obok” siebie, w izolacji, prowadzi często do takich właśnie rezultatów. Nie pozostaje to bez wpływu na losy uczniów i absolwentów, na ich funkcjonowanie w państwie, na pojmowanie tożsamości w sposób typowy dla społeczeństw państw narodowych czy narodowo-wyznaniowych.

Nową perspektywę stwarza edukacja międzykulturowa, w której tożsamość narodowa pozostaje ważnym (zapewne najważniejszym) składnikiem tożsamości, ale w której ważne miejsce zajmują kontakty z Innymi i ich kulturami, ważne są różne płaszczyzny czy wymiary tożsamości zbiorowej, społecznej.

Trzeci obszar to sprawy pojmowania i kształtowania (się) tożsamości. Po około dwustu latach kojarzenia tożsamości z identyfikacją narodową (i często religijną, wyznaniową), co więcej - z tożsamością dziedziczoną, nadaną czy zadaną - współcześnie znajduje coraz większe zrozumienie i uznanie wielowymiarowe spostrzeganie tożsamości, a jednocześnie zrozumienie własnych wyborów różnych wymiarów tożsamości (narodowego, religijnego czy światopoglądowego, kulturowego i in.). To wolny człowiek ma prawo w demokratycznym i wielokulturowym społeczeństwie dokonywać wyborów. Dla wielu ludzi jest to trudne do zaakceptowania, niektórym jest to - być może - niepotrzebne, ale też dla wielu jest to możliwość kształtowania własnej tożsamości (bez obawy odrzucenia, wyklęcia, naznaczenia piętnem zdrady jakiejś społeczności).

Przywołane obszary i kierunki zmian są, być może, zapowiedzią szerszych przeobrażeń ważnych spraw wyznaczających jakość życia, perspektywy rozwoju zintegrowanych państw i społeczeństw europejskich. Z punktu widzenia przesłań edukacji sprzyjającej pokojowemu, pomyślnemu, wspólnotowemu funkcjonowaniu społeczeństw europejskich, są to zmiany budzące nadzieje. Misją edukacji międzykulturowej - współtworzonej przez ludzi 
świadomych zarówno zagrożeń, jak i szans rozwoju współczesnych społeczeństw - jest przekonywanie do tych zmian, kształtowanie postaw opartych na uniwersalnych wartościach humanistycznych. Przyjdzie to czynić pomimo konfliktów wywoływanych przez polityków, przez rozmaite grupy lobbystów, przez ortodoksyjnych ideologów i wyznawców różnych religii, pomimo negatywnych oddziaływań mass mediów i prymitywnych zachowań rozmaitych „kiboli”, pomimo stereotypów i głupoty. Edukacja ma jednak powinność - jak ujął to Bogdan Suchodolski - wychowywania mimo wszystko ${ }^{32}$.

Taki niełatwy, ale i dający nowe, konstruktywne wizje, jest „bilans otwarcia” edukacji międzykulturowej - jako obszaru życia społecznego - i pedagogiki międzykulturowej - jako (sub)dyscypliny nauk pedagogicznych. To jednocześnie bilans otwarcia czasopisma „Edukacja Międzykulturowa”, które powinno prezentować nowe zjawiska edukacyjne i promować zmiany, o których była tu mowa.

Sprawy dotyczące edukacji, a szczególnie edukacji międzykulturowej, mogą i powinny odegrać istotną rolę w projekcie europejskiej wspólnoty. Losy demokracji (przecież najlepszego - jak dotąd - ustroju) są dość meandryczne. Ustrojowe warunki nie gwarantują jeszcze pomyślnego rozwoju. Trafnie ujął to Vaclav Havel - mówiąc, że ideał demokracji przybrał formę iluzji. Demokracja nie zapewnia spełnienia marzeń i nie daje - jak podkreślił to - dominacji wartości. O demokrację i przypisane jej wartości trzeba zabiegać, potrzebne są zmagania w skali społecznej i indywidualnej, w każdym $\mathrm{z}$ nas. I w tym pomocna powinna być edukacja.

Edukacja międzykulturowa w warunkach europejskich ma do spełnienia - jak sądzę - jeszcze inne funkcje. Wspierając integrację europejską przyczynić się może do powodzenia projektu, który wydaje się być wzorem dla społeczeństw i państw w innych częściach świata. Model kooperacyjny, demokratyczny, pokojowy - jeżeli się powiedzie - stanowić może zachętę do podobnych rozwiązań na kontynentach wciąż nękanych rozmaitymi konfliktami, wojnami. Świat, w którym z jednej strony wzorem demokracji jest jej „strażnik” wywołujący dziesiątki konfliktów zbrojnych i wojen, utrzymujący - jak wyliczono w amerykańskiej kampanii wyborczej - 700 baz wojskowych w około 100 państwach, a z drugiej strony pozostają liczne państwa i społeczeństwa na nowo skolonizowane i zdominowane, które prężą muskuły, prowadzą lokalne wojny i czekają na szansę odwetu, nie wydaje się dawać nadziei na szczęście i pokojową przyszłość. Przykład europejski może przyczynić się

32 B. Suchodolski: Wychowanie mimo wszystko. Warszawa 1990, WSiP. 
do zmiany myślenia o modelach życia we współczesnym świecie. Z myślą o przyszłości ludzi nam najbliższych, ale również i tych, którzy żyjąc gdzieś daleko także są i będą w globalnej społeczności, warto nie ustawać w edukacyjnym trudzie na rzecz wspólnotowego, zintegrowanego społeczeństwa europejskiego. Niech przewodnią myślą edukacji będzie przesłanie tradycji humanistycznej i nauki społecznej największych religii, żeby w każdym człowieku wyzwolić jak najwięcej dobrych stron jego człowieczeństwa.

\section{Bibliografia}

Bernstein B.: Odtwarzanie kultury. Warszawa 1990, PIW.

Bourdieu P., Passeron J. C.: Reprodukcja. Warszawa 1990, PWN.

DW.WORLD.EU (26.04.2012).

Eurostat - online data code:migr-pop1etz. (26.04.2012).

https:/www.cia.gov/library/publications/the-world-factbook/fields/2075. html (26.04.2012).

Kohlberg L., Mayer R.: Rozwój jako cel wychowania. W: Z. Kwieciński, L. Witkowski (red.): Spory o edukację. Warszawa 1993, IBE.

Lewowicki T.: Przemiany oświaty. Warszawa 1994, UW.

Lewowicki T.: Problemy tożsamości narodowej - w poszukiwaniu sposobów uogólnionych ujęć kwestii poczucia tożsamości i zachowań z tym poczuciem zwiazanych. W: M. Urlińska (red.): Edukacja i tożsamość etniczna. Toruń 1995, UMK.

Lewowicki T.: O badaniach społeczności pogranicza - od parcjalnych opisów ku elementom teorii zachowań tożsamościowych. W: J. Nikitorowicz (red.): Edukacja międzykulturowa: $w$ kręgu potrzeb, oczekiwań i stereotypów. Białystok 1995, „Trans Humana”.

Lewowicki T.: W poszukiwaniu modelu edukacji międzykulturowej. W: T. Lewowicki, E. Ogrodzka-Mazur, A. Szczurek-Boruta (red.): Edukacja międzykulturowa $w$ Polsce i na świecie. Katowice 2000, UŚ.

Lewowicki T., Ogrodzka-Mazur E., Szczurek-Boruta A. (red.): Edukacja międzykulturowa w Polsce i na świecie. Katowice 2000, UŚ.

Lewowicki T.: Szkic do teorii zachowań tożsamościowych. W: T. Lewowicki, E. Ogrodzka-Mazur (red.): W poszukiwaniu teorii przydatnych w badaniach międzykulturowych. Cieszyn 2001, UŚ - Filia w Cieszynie. 
Lewowicki T.: Wielokulturowość i edukacja. Tradycje i meandry edukacji wielokulturowej. „Głos Nauczycielski” 2010, nr 38.

Lewowicki T.: Wielokulturowość i edukacja - perspektywa edukacji międzykulturowej. „Głos Nauczycielski” 2010, nr 39.

Lewowicki T.: Wielokulturowość i edukacja. „Ruch Pedagogiczny” 2010, nr 3-4.

Lewowicki T.: O doświadczeniach edukacji międzykulturowej i perspektywie edukacji i pedagogiki międzykulturowej. W: T. Lewowicki, E. Ogrodzka-Mazur, A. Szczurek-Boruta (red.): Edukacja międzykulturowa - dokonania, problemy, perspektywy. Cieszyn - Warszawa - Toruń 2011, Wydział Etnologii i Nauk o Edukacji, Uniwersytet Śląski w Katowicach, Wyższa Szkoła Pedagogiczna ZNP w Warszawie, Wydawnictwo Adam Marszałek.

Lewowicki T., Ogrodzka-Mazur E., Szczurek-Boruta A. (red.): Edukacja międzykulturowa - dokonania, problemy, perspektywy. Cieszyn - Warszawa - Toruń 2011, Wydział Etnologii i Nauk o Edukacji, Uniwersytet Śląski w Katowicach, Wyższa Szkoła Pedagogiczna ZNP w Warszawie, Wydawnictwo Adam Marszałek.

Lewowicki T.: Oświata $w$ warunkach wielokulturowości - od asymilacji do edukacji międzykulturowej $i$ wielowymiarowej tożsamości. W: W. G. Kremień, T. Lewowicki, J. Nikitorowicz, S. O. Sysojewa (red.): Edukacja w społeczeństwach wielokulturowych. Warszawa 2012, Wyższa Szkoła Pedagogiczna ZNP w Warszawie, Uniwersytet w Białymstoku.

Nikitorowicz J.: Koncepcja tożsamości międzykulturowej w spoteczeństwie wielokulturowym. W: J. Gajda, J. Izdebska (red.): Kultura - wartości kształcenie wobec wyzwań i zagrożeń XXI wieku. Suwałki 2004, Wyższa Szkoła Suwalsko-Mazurska im. Papieża Jana Pawła II.

Nikitorowicz J.: Kreowanie tożsamości dziecka. Wyzwania edukacji międzykulturowej. Gdańsk 2005, GWP.

Nikitorowicz J.: Edukacja regionalna i międzykulturowa. Warszawa 2009, WAiP.

Rabczuk W.: Polityka edukacyjna Unii Europejskiej wobec mniejszości narodowych $i$ etnicznych. W: W. Rabczuk: Z problematyki pedagogiki porównawczej. Warszawa 1998, IBE.

Smolicz J. J.: Kultura i nauczanie w społeczeństwie wieloetnicznym. Warszawa 1990, PWN.

Suchodolski B.: Wychowanie mimo wszystko. Warszawa 1990, WSiP.

Szymański M. S.: Od pedagogiki dla cudzoziemców do pedagogiki między- 
kulturowej w Republice Federalnej Niemiec, czyli modernizm i postmodernizm. W: J. Nikitorowicz (red.): Edukacja międzykulturowa: w kręgu potrzeb, oczekiwań $i$ stereotypów. Białystok 1995, „Trans Humana”.

\section{Intercultural education - 2012 openning balance}

\section{Summary}

The article is a kind of balance of achievements and problems of intercultural education. It constitutes an attempt at presenting both a typology of the varieties of multiculturalism and some examples of multiculturalism in different parts of the world. This becomes a background for the outline of the history of multicultural education - its aims, applied models, and effects. What is introduced as a suggestion for overcoming the weaknesses of multicultural education is intercultural education. A new tendency in the life of contemporary societies, which the article refers to, is the multidimensional approach to human identity. In the environment of globalization, European integration, democracy and respect for human rights, the possibility to choose one's own identity is of crucial significance. The above mentioned issues, along with other things touched upon in the text, determine the important tasks of intercultural education.

Translated by Agata Cienciała 